\title{
CONTROL OF PLANT PATHOGENS - PRACTICAL EXPERIMENTS IN ERADICATION
}

\author{
J.D. FLETCHER, F.A. SHAH, R.C. BUTLER, \\ S.L.H. VILJANEN-ROLLINSON and M.V. MARRONI
The New Zealand Institute for Plant \& Food Research Limited, Christchurch, New Zealand \\ Corresponding author: fletcherj@crop.cri.nz.
}

There have been relatively few attempts to eradicate plant pathogens once they have established themselves in New Zealand. However, when concerted attempts are made very often there have been some notable successes (eg citrus canker and common smut of maize). For a successful eradication of a plant pathogen simple practical tools are needed. This research describes a series of experimental applications demonstrating the potential to eradicate seed-borne fungal and bacterial pathogens and nematode incursions. In simulated incursions seed-borne pathogens of celery were eradicated from experimental plots using solarisation and spray chemicals singly or in combination. In a simulated cyst nematode incursion Globodera rostochiensis was successfully controlled using heat treatment rather than chemical pesticides. Variations on these methods could be tailored to contain and eradicate biosecurity incursions.

\section{BACTERIA AND FUNGI ON THE SOLES OF FOOTWEAR WORN BY INTERNATIONAL AIRLINE PASSENGERS: WHAT WAS FOUND AND WHAT DOES IT MEAN?}

\author{
S.D. YOUNG and M.R. MCNEILL \\ AgResearch, Lincoln Research Centre, Private Bag 4749, Christchurch 8140 \\ Corresponding author: sandra.young@agresearch.co.nz
}

Passengers arriving on international flights to New Zealand bring with them a range of items that are considered biosecurity threats, because these items potentially carry unwanted exotic organisms. In response, New Zealand's border biosecurity officers have instigated a screening process at the airport to prevent these organisms entering New Zealand. Micro-organisms carried on footwear and clothing worn by passengers disembarking from aircraft can potentially be plant pathogens. The soles of footwear worn by passengers arriving at Christchurch International Airport were sampled for bacteria and fungi. Bacteria were recovered from $99 \%$ of the footwear examined while fungi were recovered from $78 \%$ of footwear. Seventy-three different species of bacteria were isolated, with Bacillus species the most abundant genus, although Kocuria palustris had the highest incidence of any of the bacterial genera recovered. Based on morphological identification, Penicillium, Phoma spp. and Trichoderma spp. were the most prevalent fungal genera isolated. The bacterial genera Clavibacter and Curtobacterium and the fungal genera Phoma and Botrytis were found in this study and contain species and strains that can act as plant pathogens. Killing micro-organisms adhering to passengers' footwear is problematic, since there are logistical issues in implementing an effective footwear disinfectant protocol especially during peak aircraft arrival periods. 